\title{
Synthesis and characterization of cobalt ferrites nanoparticles with cytotoxic and antimicrobial properties
}

\author{
Amal S. Hathout ${ }^{1}$, Abdulhadi Aljawish ${ }^{2,3}$, Bassem A. Sabry ${ }^{1}$, Aziza A. El-Nekeety ${ }^{1}$, Mohamed H. Roby ${ }^{4}$, \\ Nasseralla M. Deraz ${ }^{5}$, Soher E. Aly ${ }^{1}$, Mosaad A. Abdel-Wahhab ${ }^{1 *}$ \\ ${ }^{1}$ Food Toxicology \& Contaminants Departmnt, National Research Center, Dokki, Cairo, Egypt. ${ }^{2}$ Nutrition Physiology and Toxicology Laboratory \\ (NUTOX), INSERM U866, Bourgogne University, 1 Esplanade Erasme, F-21000 Dijon, France. ${ }^{3}$ ProBioGem Laboratory, EA 1026, Polytech'Lille-IUT \\ "A" Bd Paul Langevin, Villeneuve d'Ascq cedex, Université Lille Nord de France, France. ${ }^{4}$ Food Science and Technology, Faculty of Agriculture, Fayoum \\ University, Fayoum, Egypt. ${ }^{5}$ Physical Chemistry Department, National Research Center, Dokki, Cairo, Egypt.
}

\begin{tabular}{|c|c|}
\hline ARTICLE INFO & ABSTRACT \\
\hline Article history: & \multirow{10}{*}{$\begin{array}{l}\text { Recently, the application of nanotechnology in food sector and the agriculture attract the attention compared to } \\
\text { its biomedical application. The aims of the current study was to synthesize and characterize cobalt ferrites } \\
\text { nanoparticles }\left[\left(\mathrm{CoFe}_{2} \mathrm{O}_{4}\right) \text { NPs] by combustion method employing glycine as fuels and to evaluate their }\right. \\
\text { antimicrobial against pathogenic bacteria and fungi and anti cancer properties against } \mathrm{MCF}-7 \text { breast cancer cells } \\
\text { line. The results indicated that the particles size of the synthesized }\left(\mathrm{CoFe}_{2} \mathrm{O}_{4}\right) \mathrm{NPs} \text { was } 40 \mathrm{~nm} \text {. These }\left(\mathrm{CoFe}_{2} \mathrm{O}_{4}\right) \\
\mathrm{NPs} \text { showed potential antibacterial properties against Gram-negative bacteria (Escherichia coli, Salmonella } \\
\text { typhi) and Gram-positive bacteria (Staphylococcus aureus, Bacillus cereus) as well as the pathogenic fungi } \\
(\text { Aspergillus flavus and Aspergillus ochraceus) in a dose dependent manner with maximum concentration of } 1.8 \\
\mathrm{mg} / \mathrm{ml} \text {. }\left(\mathrm{CoFe}_{2} \mathrm{O}_{4}\right) \mathrm{NPs} \text { also showed weak antiradical but have cytotoxic effects against MCF-7 breast cancer } \\
\text { cells line and succeeded to decrease the cell viability at a concentration of } 2 \mathrm{mg} / \mathrm{ml} \text {. It could be concluded that } \\
\left(\mathrm{CoFe}_{2} \mathrm{O}_{4}\right) \mathrm{NPs} \text { is a promise candidate as antimicrobial and anticancer agent for food sector and medical } \\
\text { application. }\end{array}$} \\
\hline Received on: $21 / 11 / 2016$ & \\
\hline Revised on: 02/12/2016 & \\
\hline & \\
\hline Available online: $31 / 01 / 2017$ & \\
\hline & \\
\hline Food safety; antimicrobial; & \\
\hline anticancer; cobalt ferrites & \\
\hline nanoparticles; & \\
\hline nanotechnology. & \\
\hline
\end{tabular}

\section{INTRODUCTION}

Food safety is a major concern worldwide which has serious reflection on public health. Food contamination with pathogens can occur at different steps throughout the food production, processing, distribution, retail marketing, handling and preparation. Several epidemiological studies have implicated foods of animal origin as the major vehicles caused illnesses caused through food-borne pathogens (Petersen and James, 1998). Several attempts should be considered to limit the hazardous of these pathogens on human wellbeing. However, control constitutes the most significant component of overall

\footnotetext{
* Corresponding Author

Mosaad A Abdel-Wahhab, Food Toxicology \& Contaminants Departmnt, National Research Center, Dokki, Cairo, Egypt.

E-mail:mosaad_abdelwahhab@yahoo.com
}

management of food-borne pathogens. Recently, the unique properties of nanomaterials have given rise to enormous research activity towards nanoparticles fabrication and characterization as well as applications. Nanomaterials are rapidly expanding and used in various areas of research, such as food, feed, health management and environmental aspects (Bouwmeester et al. 2007; Kiruba Daniel et al. 2013). Metal-oxide nanoparticles draw attention due to their unique magnetic properties and other characteristics such as excellent chemical stability and mechanical hardness (Meng et al., 2009; Phua et al., 2009; Sanpo et al., 2013). Cobalt ferrite $\left(\mathrm{CoFe}_{2} \mathrm{O}_{4}\right)$ nanoparticles offer potential applications in several fields such as food, medicine, cancer treatment (Jamon et al., 2009) and other applications (Amiri and Shokrollahi, 2013; Sanpo et al., 2013a). These applications depend on the properties of ferrite which in turn depend on the conditions of preparation, the size and shape of the nanoparticles. 
Yamamoto (2001) enumerated the influence of particle size on the antibacterial activity and reported that the activity was increased with decreasing particle size. The antimicrobial application of magnetic nanoparticles is gaining attention because they can be manipulated through an external magnetic field. Moreover, several nonmagnetic metals nanoparticles or metal oxides were found to be antimicrobials against pathogenic bacteria (Gajjar et al., 2009). The antimicrobial activities of magnetic nanoparticles are well established by Chifiriuc et al. (2011). Cobalt ferrites nanoparticles were synthesized using different techniques such as solid state reaction (Rafferty et al., 2008) microemulsion (Choi, 2003), combustion (Yan, 1999) the redox process (Rajendran, 2001), chemical co-precipitation (Pannaparayil and Komarneni, 1989), the hydrothermal method (Daou, 2006), and microwave synthesis (Bensebaa, 2004). Generally, the evaluation of magnetic nanoparticles for drug delivery, and sensing applications are widely studied. However, the use of cobalt ferrite nanoparticles as cytotoxicity and antimicrobials against pathogenic and drug resistant microbes are not well investigated. Therefore, the aim of the current work was to study the characteristics and antimicrobial activity of prepared cobalt ferrite nanoparticle against several pathogenic microorganisms and evaluation their cytotoxic effect against MCF-7 breast cancer cells.

\section{MATERIALS AND METHODS}

\section{Preparation of cobalt ferrite nanoparticles $\left[\left(\mathrm{CoFe}_{2} \mathrm{O}_{4}\right) \mathrm{NPs}\right]$}

Cobalt ferrite nanoparticles $\left[\left(\mathrm{CoFe}_{2} \mathrm{O}_{4}\right)\right.$ NPs $]$ were prepared using the method described by Deraz (2010, 2012). In brief, the calculated proportions of iron and cobalt nitrates with a known amount of glycine, with molar ratio of 2:1:6, respectively, were mixed. The mixed precursors were concentrated in a porcelain crucible on a hot plate at $300{ }^{\circ} \mathrm{C}$ for $5 \mathrm{~min}$. The crystal water was gradually vaporized during heating and when a crucible temperature was reached, a great deal of foams produced and spark appeared at one spot which spread through the mass, yielding a brown voluminous and fluffy product in the container. The product was washed several times with water and then dried in oven at $70{ }^{\circ} \mathrm{C}$ for $2 \mathrm{~h}$.

\section{Characterization of nanoparticle}

X-ray diffraction data collection of mixed oxide solids was carried out using a BRUKER D8 advance diffractometer (Germany). Data were collected with $\mathrm{Cu} \mathrm{K \alpha}$ radiation at $40 \mathrm{KV}$ and $40 \mathrm{~mA}$ with scanning speed in $2 \theta$ of $2^{\circ} / \mathrm{min}$. Scanning electron micrographs (SEM) were recorded on JEOL JAX-840A and JEOL JEM- 1230 electron micro-analyzers, respectively. The samples were dispersed in ethanol and then treated ultrasonically in order disperse individual particles over a gold grids.

\section{Antifungal activity}

The antifungal activity of $\left(\mathrm{CoFe}_{2} \mathrm{O}_{4}\right)$ NPs was tested against fungal cultures (Aspergillus flavus and Aspergillus ochraceus). The fungal cultures were obtained from the Plant Pathology Department, National Research Centre, Cairo, Egypt. The qualitative assessment of the antifungal effect was done using well agar diffusion test. The sterilized Potato Dextrose Agar (PDA, BD Difco ${ }^{\mathrm{TM}}$, MD 21152, USA) medium was poured into petri plates and allowed to dry. Test cultures were inoculated over the dried surface of PDA plate. The appropriate number of wells was bored into the plates using sterile cork borer of 9-mm in diameter. Different concentrations of $\left(\mathrm{CoFe}_{2} \mathrm{O}_{4}\right)$ NPs were added to these wells and incubated for 7 days at $25 \pm 2{ }^{\circ} \mathrm{C}$. The contact biocidal property was determined by measuring the diameter of the zone of inhibition around the well.

\section{Antibacterial activity}

The antibacterial activity of $\left(\mathrm{CoFe}_{2} \mathrm{O}_{4}\right)$ NPs was tested against bacterial cultures of Gram-negative bacteria (Escherichia coli, Salmonella typhi) and Gram-positive bacteria (Staphylococcus aureus, Bacillus cereus). The pathogenic bacteria were obtained from the Department of Microbial Chemistry, National Research Centre, Cairo, Egypt. The bacteria were pregrown on Nutrient agar (NA, Sigma-Aldrich, St. Louis, MO63103, USA) for $16 \mathrm{~h}$ at $37.0 \pm 0.1^{\circ} \mathrm{C}$. The qualitative assessment of the antibacterial effect was done using two approaches (Disk Diffusion test and Bacterial Linear growth). Disc diffusion assay was determined using the protocol of Jorgensen and Turnidge (2007). Overnight grown bacterial cultures in nutrient broth were individually lawn cultured on nutrient agar plates. Three $\left(\mathrm{CoFe}_{2} \mathrm{O}_{4}\right)$ NPs concentrations $(0.6,0.8$ and $1.8 \mathrm{mg} / \mathrm{mL})$ were prepared in sterile water and dispensed by sonication. Sterile filter paper discs $(5.0-\mathrm{mm})$ were saturated by the $\left(\mathrm{CoFe}_{2} \mathrm{O}_{4}\right)$ NPs solution and placed above the culture and incubated at $37 \pm 0.1^{\circ} \mathrm{C}$ for $24 \mathrm{~h}$ after which the zone of inhibition were recorded. Sterile filter paper was saturated with sterile water and used as control. The same concentrations for bacterial linear growth were examined whereas each concentration was individually set in three petri dishes. The NA medium was poured in the plates and rotated to ensure an even distribution of the nanoparticle. Control Petri dishes were prepared containing no $\left(\mathrm{CoFe}_{2} \mathrm{O}_{4}\right)$ NPs. Petri dishes were individually inoculated at the center with equal disks (5.0$\mathrm{mm}$ ) of tested bacterial cultures. The average linear growth of each bacterium was measured after $24 \mathrm{~h}$ of incubation at $37.0 \pm 0.1^{\circ} \mathrm{C}$.

\section{DPPH and ABTS free radical scavenging assay of $\left(\mathrm{CoFe}_{2} \mathrm{O}_{4}\right)$} NPs

$\left(\mathrm{CoFe}_{2} \mathrm{O}_{4}\right)$ NPs at different concentrations was mixed with $2 \mathrm{ml}$ of methanol solution containing $\mathrm{DPPH}^{*}$ radicals resulting in a final concentration of $6.10^{-5} \mathrm{M} \mathrm{DPPH}^{\circ}$. The mixture was shaken vigorously for $15 \mathrm{~s}$ and then left to stand in the dark at room temperature for $30 \mathrm{~min}$. The absorbance (Abs) of the resulting solution was measured at $517 \mathrm{~nm}$ using a UV-visible spectrophotometer (Shimadzu UV-1605) against methanol as a blank according to the method described by Shimada et al. (1992). The scavenging ability was calculated by the following equation:

DPPH Scavenging ability $(\%)=\left(1-\mathrm{Abs}_{\text {sample }} / \mathrm{Abs}_{\text {control }}\right) \times 100$ 
$\mathrm{DPPH}^{*}$ radical scavenging activity was expressed as the half-maximal inhibition concentrations $\left(\mathrm{IC}_{50}\right) . \mathrm{IC}_{50}$ value, which expressed as the antioxidant concentration to reduce the radicals by $50 \%$, was calculated for each compound by linear regression analysis (Gulcin, 2010).

The ABTS radical scavenging activity of $\left(\mathrm{CoFe}_{2} \mathrm{O}_{4}\right) \mathrm{NPs}$ was determined according to the method described by $\operatorname{Re}$ et al. (1999). The reaction between $7 \mathrm{mM}$ ABTS and $2.45 \mathrm{mM}$ potassium persulfate in $\mathrm{H}_{2} \mathrm{O}$ made the $\mathrm{ABTS}^{++}$radical cation. The last solution was left to stand in the dark, at room temperature, for $12-16 \mathrm{~h}$ before use. Before analysis, the $\mathrm{ABTS}^{++}$solution was diluted with ethanol at $30^{\circ} \mathrm{C}$, in order to obtain an absorbance of $0.700 \pm 0.025$ at $734 \mathrm{~nm}$. Then, different concentrations of $\left(\mathrm{CoFe}_{2} \mathrm{O}_{4}\right)$ NPs in solid form were mixed with $1 \mathrm{ml}$ of diluted ABTS $^{++}$solution. The mixture was shaken vigorously for $15 \mathrm{~s}$ and then left to stand in the dark at room temperature for $20 \mathrm{~min}$. The absorbance of $\mathrm{ABTS}^{++}$was measured at $734 \mathrm{~nm}$ against ethanol as a blanck. The extent of decolorization is calculated as the percentage reduction of ABTS absorbance by following equation:

$\mathrm{ABTS}^{\cdot+}$ radical scavenging activity $(\%)=\left(1-\mathrm{Abs}_{\text {sample }} / \mathrm{Abs}_{\text {control }}\right)$ $\mathrm{x} 100$

$\mathrm{ABTS}^{++}$radical scavenging activity was expressed as the half-maximal inhibition concentrations $\left(\mathrm{IC}_{50}\right)$. All analyses were carried out in triplicate and results represented the mean values with standard deviation.

\section{Anti-proliferative activity \\ Cell culture}

MCF-7 (ECACC, United Kingdom) breast cancer cells line were cultured in monolayers at in Dulbecco's modified eagle medium (DMEM) medium (Sigma, Germany), with 10\% fetal bovine serum (FBS) (EuroBio, France) and $1 \%$ of antibiotic penicillin-streptomycin (GIBCO, USA). The cells were usually split when reaching confluence (2-3 days). They were first rinsed with Dulbecco's phosphate-buffered saline without calcium (DPBS) (Sigma, Germany) and then trypsinised with a solution containing $0.25 \%$ trypsin and $1 \mathrm{mM}$ EDTA (GIBCO, USA). MCF7 breast cancer cells lines were seeded into 96-well microplates at $5 \times 10^{4}$ cells/well in $200 \mu \mathrm{l}$ of appropriate culture medium. After 24 $\mathrm{h}$, the cells were exposed to $0.2 \mathrm{mg}$ (final concentration $1 \mathrm{mg} / \mathrm{ml}$ ) of $\left(\mathrm{CoFe}_{2} \mathrm{O}_{4}\right)$ NPs and then incubated for $48 \mathrm{~h}$ at $37{ }^{\circ} \mathrm{C}$, under $5 \%$ $\mathrm{CO}_{2}$ atmosphere. A control was used without $\left(\mathrm{CoFe}_{2} \mathrm{O}_{4}\right)$ NPs with the same conditions.

\section{Cell viability}

The number of living cells was determined using methyl thiazolyldiphenyl-tetrazolium bromide (MTT) assay (Sigma, Germany) based on the reduction of the tetrazolium salt, methyl thiazolyldiphenyl-tetrazolium bromide into a crystalline blue formazan product by the cellular oxidoreductases of viable cells (Maher and McClean, 2006). The resultant formazan crystal formation is proportional to the number of living cells. After the incubation for 2 days, $250 \mu \mathrm{l}$ of MTT $(2 \mathrm{mg} / \mathrm{ml}$ in PBS, pH 7.4) were added to all wells and the plate was then incubated at $37{ }^{\circ} \mathrm{C}$ under $5 \% \mathrm{CO}_{2}$ atmosphere for $4 \mathrm{~h}$. Medium with MTT was then gently removed and $1 \mathrm{ml}$ of isopropanol $(60 \%)$ was added to all wells for dissolving of the formazan crystals. The plates were then shaken at room temperature for $10 \mathrm{~min}$ and the absorbance was read at $540 \mathrm{~nm}$ in a microplate reader. The relative cell viability was calculated according to the following equation:

$$
\text { Relative cell viability }(\%)=\left[\left(1-\left(\mathrm{Abs}_{\text {treated cell }} / \mathrm{Abs}_{\text {control }}\right)\right] \times 100\right.
$$

Where Abs treated cells and Abs control are the absorbance values at 540 $\mathrm{nm}$ of sample with treated cells and control, respectively. Each test was carried out in six copies, and each experiment was repeated triplicate. For analysis of cell morphology and spreading, images of MCF-7 breast cancer cells were taken after 2 days incubation. The cell images were taken at 10x magnification using an inverted optical microscope (Olympus, Tokyo, Japan) equipped with a digital camera (DXM1200F, Nikon).

\section{Statistical analysis}

All data were statistically analyzed using the General Linear Models Procedure of the Statistical Analysis System SAS (1982). The significance of the differences among treatment groups was determined by Waller-Duncan k-ratio. All statements of significance were based on probability of $\mathrm{P} \leq 0.05$.

\section{RESULTS AND DISCUSSION}

$\mathrm{RD}$ investigation of the synthesized sample showed that all the characteristic peaks of spinel $\mathrm{CoFe}_{2} \mathrm{O}_{4}$ phase with crystallite size of their particles $40 \mathrm{~nm}$ (Deraz, 2010, 2012). The microstructure of $\left(\mathrm{CoFe}_{2} \mathrm{O}_{4}\right)$ NPs was analyzed using SEM technique and the micrograph showed the formation of spongy and fragile network structure (Fig. 1).

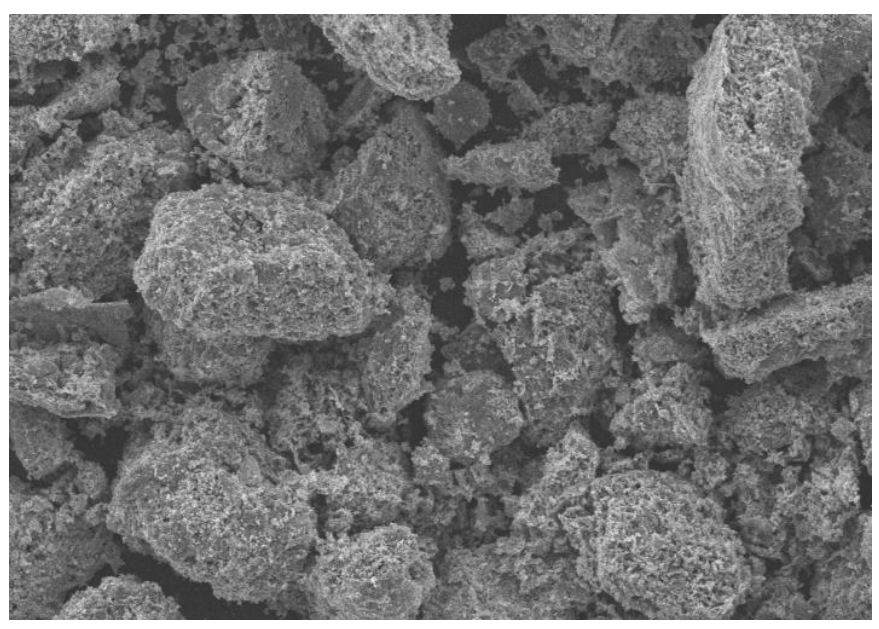

Fig. 1: SEM image for $\left(\mathrm{CoFe}_{2} \mathrm{O}_{4}\right)$ NPs. 


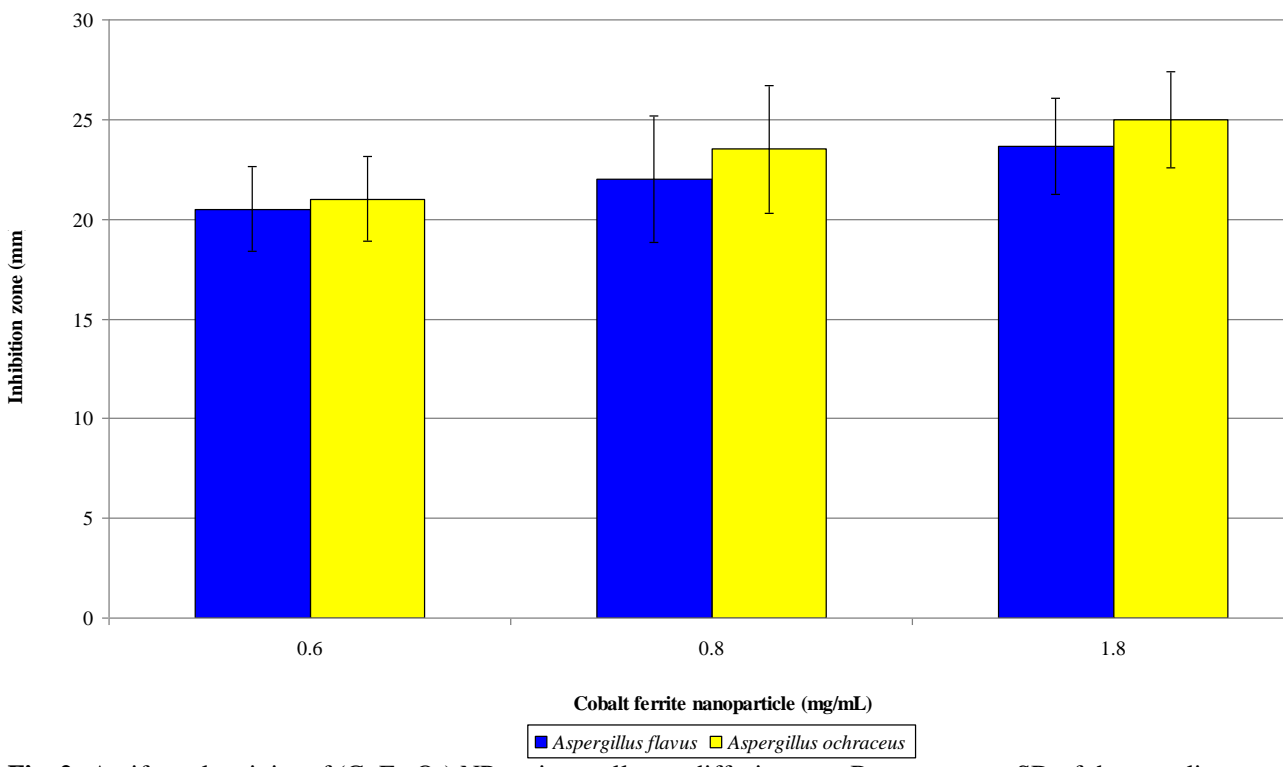

Fig. 2: Antifungal activity of $\left(\mathrm{CoFe}_{2} \mathrm{O}_{4}\right) \mathrm{NPs}$ using well agar diffusion test. Bars represent $\mathrm{SD}$ of three replicates.

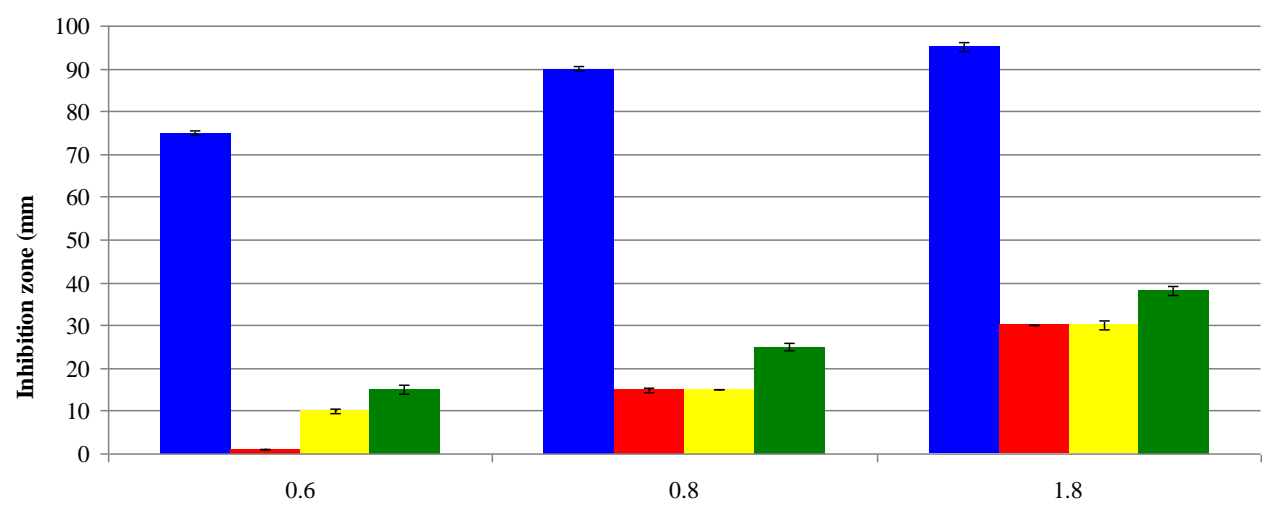

Cobalt ferrite nanoparticle $(\mathrm{mg} / \mathrm{mL})$

- Bacillus cereus $\quad$ Staphylococcus aureus $\quad$ Salmonella typhi $\mathbf{E}$ Escherichia coli

Fig. 3: Antimicrobial activity of cobalt ferrite nanoparticles using disk diffusion test. Bars represent SD of two replicates.

\section{Antimicrobial activity}

The antifungal activity of $\left(\mathrm{CoFe}_{2} \mathrm{O}_{4}\right)$ NPs was tested against fungal cultures (Aspergillus flavus and Aspergillus ochraceus). The qualitative assessment of the antifungal effect was done using well agar diffusion test and the current results showed that the highest antifungal activity of $\left(\mathrm{CoFe}_{2} \mathrm{O}_{4}\right) \mathrm{NPs}$ was recorded at concentration $1.8 \mathrm{mg} / \mathrm{mL}$ against Aspergillus flavus and Aspergillus ochraceus although no significant difference was observed between the three tested concentrations of $\left(\mathrm{CoFe}_{2} \mathrm{O}_{4}\right)$ NPs. The zone inhibition of $A$. ochraceus was absent at concentration of $0.8 \mathrm{mg} / \mathrm{mL}\left(\mathrm{CoFe}_{2} \mathrm{O}_{4}\right)$ NPs (Fig. 2).

Although there is limited data about the use of $\left(\mathrm{CoFe}_{2} \mathrm{O}_{4}\right) \mathrm{NPs}$ against pathogenic fungi, Chifiriuca et al. (2011) reported that $\left(\mathrm{CoFe}_{2} \mathrm{O}_{4}\right)$ NPs produce a strong inhibitory effect on the adherence to the cellular substrate of $C$. albicans strains. On the other hand, the use of other metals nanoparticles such as $\mathrm{ZnO}$ showed antifungal activity against Aspergillus, Fusarium, Penicillium etc. (He et al., 2011; Lipovsky et al., 2011; Chitra and Annadurai 2013; Dimkpa et al., 2013). The antifungal activity of metals nanoparticle may be due to suppression of extracellular enzymes and metabolites that helps its survival when exposed to stress as reported by Bhainsa and D' Souza (2006) and Vahabi et al. (2011).

The antibacterial activity of $\left(\mathrm{CoFe}_{2} \mathrm{O}_{4}\right)$ NPs was qualitatively measured by performing disk diffusion test against pathogenic microorganisms (Bacillus cereus, Staphylococcus aureus, Salmonella typhi and Escherichia coli). The absence of growth around the nanoparticle is an indirect measure of the ability of the material to inhibit the bacteria growth. The zone inhibition produced by the nanoparticle against the gram negative and the gram positive bacteria is shown in Fig. (3). These results revealed that $\left(\mathrm{CoFe}_{2} \mathrm{O}_{4}\right)$ NPs efficiently inhibited the growth of the microbes, whereas $B$. cereus was the most sensitive microorganism to the nanoparticles. It was also noticed that the 
zone inhibition was increased by increasing the concentration from 0.6 to $1.8 \mathrm{mg} / \mathrm{mL}$ of $\left(\mathrm{CoFe}_{2} \mathrm{O}_{4}\right) \mathrm{NPs}$. The effect of $\left(\mathrm{CoFe}_{2} \mathrm{O}_{4}\right) \mathrm{NPs}$ on bacterial linear growth (Fig. 4) revealed that the bacterial growth was decreased by increasing the concentrations of the nanoparticles. Similar results were reported by Sanpo et al. (2013a) who reported an antibacterial activity of $\left(\mathrm{CoFe}_{2} \mathrm{O}_{4}\right)$ NPs against $E$. coli and $S$. aureus. In the same trend the rate of inhibition of E.coli was higher than that of $S$. aureus. The current results are in good harmony with several authors who reported that the nanocomposites of $\mathrm{CoFe}_{2} \mathrm{O}_{4}$ (Sanpo et al., 2013), polyaniline and nanosilver (Kooti et al., 2014), and $\mathrm{CoFe}_{2} \mathrm{O}_{4} / \mathrm{SiO} 2 / \mathrm{Ag}$ composite (Kooti et al., 2015) showed high antibacterial activity. Moreover, Antoniea et al. (2012) found that the magnetite and $\left(\mathrm{CoFe}_{2} \mathrm{O}_{4}\right)$ NPs induced the most significant effects in $S$. aureus and B. subtilis. Grumezescu et al. (2010) studied the effect of $\left(\mathrm{CoFe}_{2} \mathrm{O}_{4}\right) /$ oleic acid nanoparticles and found that they induced inhibitory effects on clinical isolates of bacterial and fungal strains at concentrations between 1000 and $1.9 \mu \mathrm{g} / \mathrm{mL}$. Another study conducted by Sanpo et al. (2013b), the authors focused on the influence of chelating agents, namely polyvinyl alcohol and citric acid, on the microstructure and antibacterial property of cobalt ferrite nanopowders, and demonstrated that both types of cobalt ferrite nanopowders showed an effective antibacterial activity against E. coli and S. aureus Several mechanisms have been suggested for the antibacterial action of nanoparticles. However, the actual inhibitory mechanism of the nanoparticles may require further studies (Moritz and Moritz, 2013). The antimicrobial activity of the nanoparticles is known to be the function of surface area which is adhesion to the microorganisms. The small size and the high surface to volume ratio i.e., large surface area enhances the interaction between the nanoparticles and the microbes to carry out a broad range of probable antimicrobial activities (Ravishankar and Jamuna, 2011).

Moreover, Vidya and Venkatesan (2015) suggested that nanoparticle bind to the membranes of microorganisms which can prolong the lag phase of the growth cycle and increase the generation time of the organisms. Other mechanisms contributing to the occurrence of antibacterial activity of nanoparticles is the release of reactive oxygen species (ROS) such as hydrogen peroxide $\left(\mathrm{H}_{2} \mathrm{O}_{2}\right)$ and super-oxide $\left(\mathrm{O}^{2-}\right)$ generated from the surface of nanoparticles (Sawai, 2003; Hashim et al., 2013). Furthermore, the penetration rate of an active oxide through the bacteria cell wall may play a part in the bacterial killing rate by nanoparticles (Xavier et al., 2014).

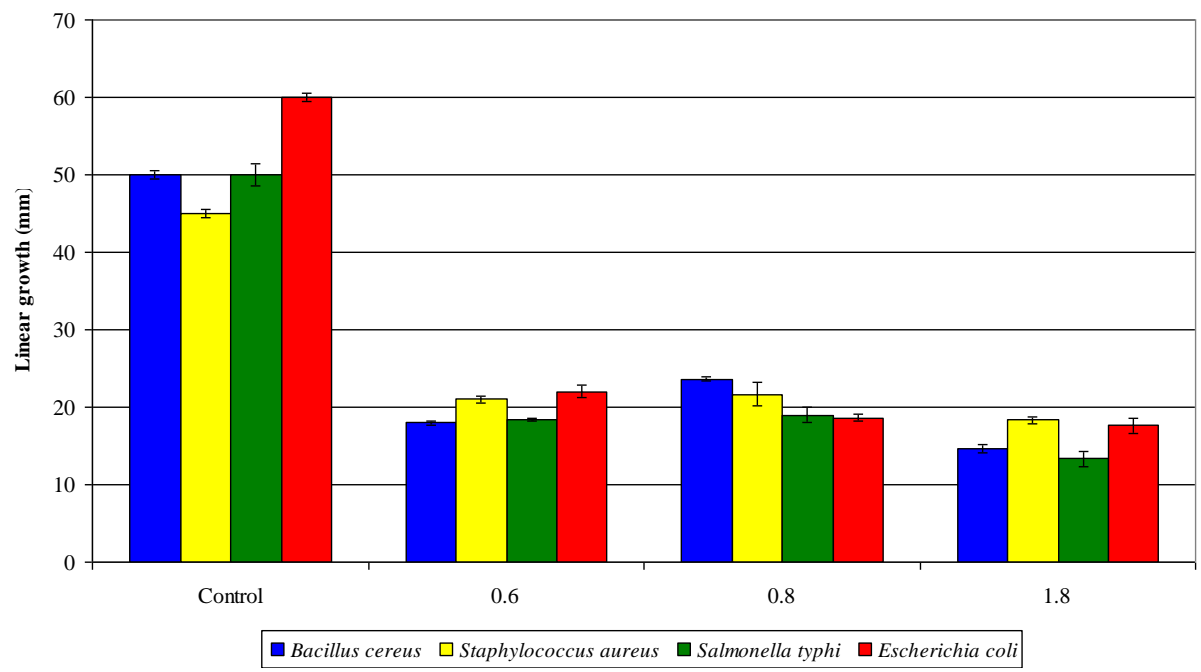

Fig. 4: Linear growth of pathogenic bacteria after treatment with different concentrations of cobalt ferrite nanoparticle. Bars represent SD of three replicates.

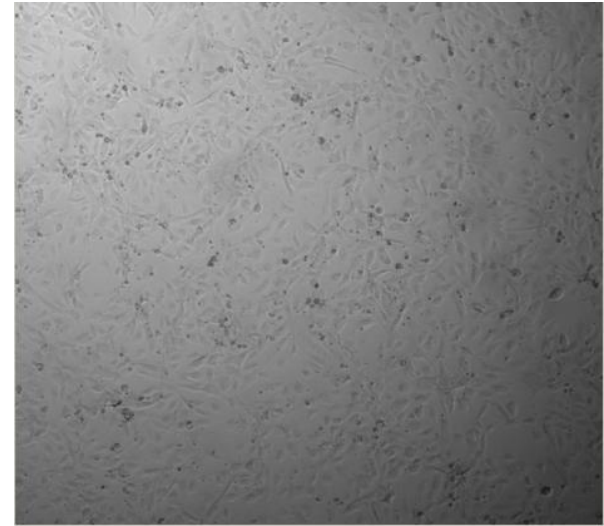

A

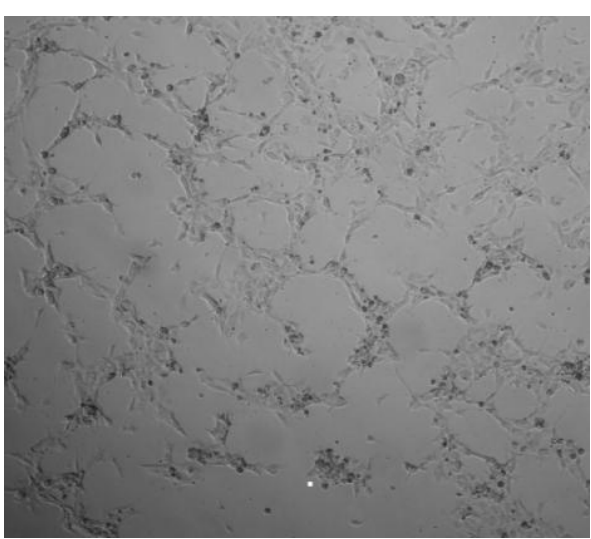

B

Fig. 5: Photos of MCF-7 breast cancer cells cultivated for 2 days (A) and after incubation with $0.1 \mathrm{mg} / \mathrm{mL}\left(\mathrm{CoFe}_{2} \mathrm{O}_{4}\right) \mathrm{NPs}$ (B) by optical microscope (10x magnifications). 
Antiradical properties by DPPH free radical scavenging and ABTS radical cation decolorization assays

The results of DPPH and ABTS radical scavenging activities of $\left(\mathrm{CoFe}_{2} \mathrm{O}_{4}\right)$ NPs were expressed as the half-maximal inhibition concentrations $\left(\mathrm{IC}_{50}\right)$. These results showed that $\mathrm{IC}_{50}$ values in DPPH and ABTS scavenging of $\left(\mathrm{CoFe}_{2} \mathrm{O}_{4}\right)$ NPs were determined as $6.8 \pm 0.20 \mathrm{mg} / \mathrm{ml}$ and $0.25 \pm 0.02 \mathrm{mg} / \mathrm{ml}$, respectively. However, natural standard antioxidant Trolox as vitamin $\mathrm{E}$ analogue and ascorbic acid as vitamin $\mathrm{C}$ have $\mathrm{IC}_{50}$ values at $2.19 \pm 0.02 \mu \mathrm{g} / \mathrm{ml}$ and $5.3 \pm 0.3 \mu \mathrm{g} / \mathrm{ml}$, respectively in ABTS scavenging (Aljawish et al., 2014). By comparing with this standard antioxidant, $\left(\mathrm{CoFe}_{2} \mathrm{O}_{4}\right)$ NPs are considered as weak antioxidant because the release of reactive oxygen species (ROS) generated from the surface of nanoparticles (Hashim et al., 2013).

\section{Anti-proliferative activity}

The effect of $\left(\mathrm{CoFe}_{2} \mathrm{O}_{4}\right)$ NPs on MCF-7 breast cancer cells lines (Figs. 5A, B) indicated that exposure of the breast cell lines to $1 \mathrm{mg} / \mathrm{mL}$ of $\mathrm{CoFe}_{2} \mathrm{O}_{4}$ NPs resulted in a significant decrease in the cell viability and the relative cell viability reached $63 \pm 3.6 \%$. It is well documented that the effect of a compound on tumor cells is mainly due to their oxidative stress effects. Tumor cells may, however, be dependent on a certain amount of hydrogen peroxide and the deficiency of hydrogen peroxide may resulted in cell cycle arrest or apoptosis of these cells (Loo, 2003). Similar to the current results, Horev-Azaria et al. (2013) reported that the viability of cell-lines towards the $\left(\mathrm{CoFe}_{2} \mathrm{O}_{4}\right)$ NPs may be mainly attributed to their ability to interact with NPs in case of either the adsorption of NPs to the cell surface and/or the uptake of NPs by the cells. Moreover, Nel et al. (2006) reported that oxidative stress which defined as the imbalance between the antioxidant defenses and the production of reactive oxygen species (ROS) or reactive nitrogen species (RNS) is considered to be the most important mechanism of NPs-induced hazards effects. In this concern, Horev-Azaria et al. (2013) found a high linear correlation between the toxicity of $\left(\mathrm{CoFe}_{2} \mathrm{O}_{4}\right)$ NPs and the amount of generated ROS following the exposure to $\left(\mathrm{CoFe}_{2} \mathrm{O}_{4}\right)$ NPs. Previous study showed that NPs could generate ROS, exhaust endogenous antioxidants, affect the function of mitochondria and induce oxidative damage to DNA and lipids (Moller et al., 2010). Consequently, NPsinduced ROS activation encourages the elements of defense antioxidant response and if damage proceeds, the protective systems activate protein kinase and NF- $\kappa \mathrm{B}$-activated intracellular signaling which resulted in the release of pro-inflammatory cytokine, matrix metalloproteinase and chemokine leading to apoptosis (Shubayev and Pisanic, 2009).

\section{CONCLUSION}

The current results indicated that $\left(\mathrm{CoFe}_{2} \mathrm{O}_{4}\right)$ NPs can be synthesized by combustion method using glycine as fuel and the average particles size was $40 \mathrm{~nm}$. The synthesized $\left(\mathrm{CoFe}_{2} \mathrm{O}_{4}\right) \mathrm{NPs}$ showed a potential antimicrobial activity against gram positive and gram negative bacteria as well as the pathogenic fungi Aspergillus flavus and Aspergillus ochraceus in a dose dependent manner. The concentration of $1.8 \mathrm{~g} / \mathrm{ml}$ of $\left(\mathrm{CoFe}_{2} \mathrm{O}_{4}\right)$ NPs showed maximum growth inhibition for all bacteria and fungi tested. Moreover the tested $\left(\mathrm{CoFe}_{2} \mathrm{O}_{4}\right)$ NPs at a concentration of $2 \mathrm{mg} / \mathrm{ml}$ showed weak antiradical activity but have high cytotoxic effects against MCF-7 breast cancer cells lines and succeeded to decrease the cell viability by about $63 \%$. These findings suggested that the toxicity of $\left(\mathrm{CoFe}_{2} \mathrm{O}_{4}\right)$ NPs is partially due to oxidative stress. The antimicrobial and anticancer properties of $\left(\mathrm{CoFe}_{2} \mathrm{O}_{4}\right)$ NPs reported herein give these NPs great advantages to be used in food and biomedical applications.

\section{ACKNOWLEDGMENT}

Financial support and sponsorship: This work was funded by the National Research Centre, Cairo, Egypt, under grant \#10070208.

Conflict of Interests: There are no conflicts of interest.

\section{REFERENCES}

Aljawish A, Chevalot I, Jasniewski J, Paris C, Scher J, Muniglia L. Laccase-catalysed oxidation of ferulic acid and ethyl ferulate in aqueous medium: a green procedure for the synthesis of new compounds. Food Chem, 2014; 145: 1046-1054.

Amiri S, Shokrollahi $\mathrm{H}$. The role of cobalt ferrite magnetic nanoparticles in medical science. Mater Sci Eng, 2013; 33 (1): 1-8.

Antoniea P, Dorina C, Claudia N, Mihai TF. Electromagnetic exposure and magnetic nanoparticle impact on some bacteria. African $\mathrm{J}$ Microbiol Res, 2012; 6(5): 1054-1060.

Bensebaa F. Microwave synthesis and characterization of Coferrite nanoparticles. J Colloid Interface Sci, 2004; 277 (1): 104-110.

Bhainsa KC, D'Souza SF. Extracellular biosynthesis of silver nanoparticles using the fungus Aspergillus fumigatus. Colloids Surf B, 2006; 47(2): 160-164.

Bouwmeester H, Dekkers S, Noordam M, Hagens W, Bulder A, De Heer C, Ten Voorde S, Wijnhoven S, Sips A. Health impact of nanotechnologies in food production. Wageningen UR, RIKILT. Report 2007.014, published by RIKILT-Institute of Food Safety, Wageningen UR and National Institute of Public Health \& the Environment-Centre for Substances and Integrated Risk Assessment. Accessed from http://edepot.wur.nl/ 120669; 2007; pp 1-91.

Chifiriuc C, Lazar V, Bleotu B, Calugarescu I, Rumezescu AM, Mihaiescu DE, Mogoşanu DE, Buteica AS, Buteica E. Bacterial adherence to the cellular and inert substrate in the presence of $\mathrm{CoFe}_{2} \mathrm{O}_{4}$ and $\mathrm{Fe}_{3} \mathrm{O}_{4}$ /oleic acid-core/shell. Digest J Nanomater Biostruct, 2011.; 6(1): $37-42$.

Chitra K, Annadurai G. Antimicrobial activity of wet chemically engineered spherical shaped $\mathrm{ZnO}$ nanoparticles on food borne pathogen. Int Food Res J, 2013; 20(1):59-64.

Choi EJ. Superparamagnetic relaxation in $\mathrm{CoFe}_{2} \mathrm{O}_{4}$ nanoparticles. J Magn Magn Mater, 2003; 262 (2): L198-L202.

Daou TJ. Hydrothermal synthesis of monodisperse magnetite nanoparticles. Chem Mater, 2006;18 (18): 4399-4404.

Deraz NM. Glycine-assisted fabrication of nanocrystalline cobalt ferrite system. J Analyt Appl Pyrolysis, 2010; 88(2), 103-109.

Deraz NM. Production, Physicochemical Characterization and Magnetic Behavior of Nanocrystalline Al- Doped Co/Fe System. Int J Electrochem Sci, 2012; 7: 4596-4607

Dimkpa CO, McLean JE, Britt DW, Anderson AJ. Antifungal activity of $\mathrm{ZnO}$ nanoparticles and their interactive effect with a biocontrol bacterium on growth antagonism of the plant pathogen, Fusarium graminearum. BioMetals, 2013; 26:913-24. 
Gajjar P, Pettee B, Britt DW, Huang W, Johnson WP, Anderson AJ. Antimicrobial activities of commercial nanoparticles against an environmental soil microbe, Pseudomonas putida KT2440. J Biol Eng, 2009; 3: 9-22.

Grumezescu AM, Mihaiescu DE, Mogosanu DE, Chifiriuc MC, Lazar V, Calugarescu I, Traistaru V. In vitro assay of the antimicrobial activity of $\mathrm{Fe}_{3} \mathrm{O}$ and $\mathrm{CoFe}_{2} \mathrm{O}_{4}$ / oleic acid-core/shell on clinical isolates of bacterial and fungal strains. Optoel Adv Mater Rapid Commun, 2010; 4(11): 1798-1801.

Gulcin I, Bursal E, M. Şehitoĝlu MH, Bilsel M, Goren AC. Polyphenol contents and antioxidant activity of lyophilized aqueous extract of propolis from Erzurum, Turkey. Food Chem Toxicol, 48; 2227. 2238.

Hashim M, Alimuddin SE, Meena SS, Kotnala RK, Ameena, P, Aashis SR, Shalendra K, Pramod B, Kumar R. Investigation of structural, dielectric, magnetic and antibacterial activity of $\mathrm{Cu}-\mathrm{Cd}-\mathrm{Ni}-\mathrm{FeO}_{4}$ nanoparticles. Magn Magn Mater, 2013; 341: 148-157.

He L, Liu Y, Mustapha A, Lin M. Antifungal activity of zinc oxide nanoparticles against Botrytis cinerea and Penicillium expansum. Microbiol Res, 2011; 166: 207-215.

Horev-Azaria L, Baldi G, Beno D, Bonacchi D, Golla-Schindler U, Kirkpatrick JC, Kolle S, Landsiedel R, Maimon O, Marche PN, Ponti J, Romano R, Rossi F, Sommer D, Uboldi C, Unger RE, Villiers C, Korenstein R. Predictive toxicology of cobalt ferrite nanoparticles: comparative in-vitro study of different cellular models using methods of knowledge discovery from data. Part Fibre Toxicol, 2013; 10:32, 17 pages. doi: 10.1186/1743-8977-10-32.

Jamon D, Donatini F, Siblini A, Royer F, Perzynski R, Cabuil $\mathrm{V}$, Neveu S. Experimental investigation on the magneto-optic effects of ferrofluids via dynamic measurements. J Magn Magn Mater, 2009; 321: $1148-1154$

Jorgensen JH, Turnidge JD. Susceptibility test methods: dilution and disk diffusion methods, p. 1152-1172. In Murray PR, Baron EJ, Jorgensen JH, Landry ML, Pfaller MA (ed.), Manual of clinical microbiology, $9^{\text {th }}$ ed. ASM Press, Washington DC. 2007.

Kiruba DSCG, Vinothini G, Subramanian N, Nehru K, Sivakumar M. Biosynthesis of $\mathrm{Cu}, \mathrm{ZVI}$, and $\mathrm{Ag}$ nanoparticles using Dodonaea viscosa extract for antibacterial activity against human pathogens. J Nanopart Res, 2013; 15(1):1319-1328.

Kooti M, Gharineh S, Mehrkhah M, Shaker A, Motamedi H. Preparation and antibacterial activity of $\mathrm{CoFe}_{2} \mathrm{O}_{4} / \mathrm{SiO}_{2} / \mathrm{Ag}$ composite impregnated with streptomycin. Chem Eng J, 2015; 259: 34-42.

Kooti M, Kharazi P, Motamedi H. Preparation, characterization, and antibacterial activity of $\mathrm{CoFe} 2 \mathrm{O} 4 /$ polyaniline/Ag nanocomposite. J Taiwan Institute Chem Engin, 2014; 45 (5): 2698-2704.

Lipovsky A, Nitzan Y, Gedanken A, Lubart R. Antifungal activity of $\mathrm{ZnO}$ nanoparticles-the role of ROS mediated cell injury. Nanotechnol, 2011; 22(10): 105101.

Loo G. Redox-sensitive mechanisms of phytochemicalmediated inhibition of cancer cell proliferation (Review). J Nut Biochem, 2003; 14(2): 64-73.

Maher S, McClean S. Investigation of the cytotoxicity of eukaryotic and prokaryotic antimicrobial peptides in intestinal epithelial cells in vitro. Biochem Pharmacol ,2006;71(9): 1289-1298.

Meng X, Li H, Chen J, Mei L, Wang K, Li X. Mossbauer study of cobalt ferrite nanocrystals substituted with rare-earth Y3+ ions. J Magn Magn Mater 2009; 321: 1155-1158.

Moller P, Jacobsen NR, Folkmann JK, Danielsen PH, Mikkelsen L, Hemmingsen JG, Vesterdal LK, Forchhammer L, Wallin H, Loft S. Role of oxidative damage in toxicity of particulates. Free Radic Res, 2010; 44(1):1-46.

Moritz M, Moritz MG. The newest achievements in synthesis, immobilization and practical applications of antibacterial nanoparticles. Chem Eng J, 2013; 228: 596-613.

Nel A, Xia T, Madler L, Li N. Toxic potential of materials at the nanolevel. Science 2006; 311(5761):622-627.
Pannaparayil T, Komarneni S. Synthesis and characterization of ultrafine cobalt ferrites. IEEE Trans on Magn, 1989;25 (5): 4233-4235.

Petersen KE, James WO. Agents, vehicles, and causal inference in bacterial food borne disease outbreaks: 82 reports (1986-1995). J Am Vet Med Assoc, 1998; 212:1874-1881.

Phua LX, Xu F, Ma YG, Ong CK. Structure and magnetic characterizations of cobalt ferrite films prepared by spray pyrolysis. Thin Solid Films 2009; 517: 5858-561.

Rafferty A, Prescott T, Brabazon D. Sintering behavior of cobalt ferrite ceramic. Ceram Int, 2008; 34 (1): 15-21.

Rajendran M. Magnetic properties of nanocrystalline $\mathrm{CoFe}_{2} \mathrm{O}_{4}$ powders prepared at room temperature: variation with crystallite size. $\mathbf{J}$ Magn Magn Mater, 2001; 232 (1-2): 71-83.

Ravishankar RV, Jamuna BA. Nanoparticles and their potential application as antimicrobials. In: Science against microbial pathogens: communicating current research and technological advances. MéndezVilas, A. (Ed.), 2011; pp.197-209.

Re R, Pellegrini N, Proteggente A, Pannala A, Yang M, RiceEvans C. Antioxidant activity applying an improved ABTS radical cation decolorization assay. Free Rad Biol Med, 1999; 26(9-10): 1231-1237.

Sanpo N, Berndt CC, Wen C, Wang J. Transition metalsubstituted cobalt ferrite nanoparticles for biomedical applications. Acta Biomate, 2013; 9: 5830-5837.

Sanpo N, Berndt CC, Cuie W, James W. Transition-metal substituted cobalt ferrite nanopartice for biomedical applications. Acta Biomater, 2013a; 9: 5830-5837.

Sanpo N, Wang J, Berndt CC. Influence of chelating agents on the microstructure and antibacterial property of cobalt ferrite nanopowders. J Aust Ceram Soc, 2013b; 49 (1): 84-91

SAS.Institute Inc., SAS User's Guide: Statistics. SAS Institute Inc., Cary, 1982; NC.

Sawai JJ Quantitative evaluation of antibacterial activities of metallic oxide powders $(\mathrm{ZnO}, \mathrm{MgO}$ and $\mathrm{CaO})$ by conductimetric assay. Microbiol Meth 2003; 54(2): 177-182.

Shimada K, Fujikawa K, Yahara K, Nakamura T. Antioxidative Properties of xanthan on the autoxidation of soybean oil in cyclodextrin emulsion. J Agric Food Chem, 1992; 40(6): 945-948.

Shubayev VI, Pisanic TR, Jin S. Magnetic nanoparticles for theragnostics. Adv Drug Deliv Rev, 2009; 61(6):467-477.

Vahabi K, Mansoori GA, Karimi S. Biosynthesis of silver nanoparticles by fungus Trichoderma reesei (a route for largescale production of AgNPs). Insc J, 2011; 1(1): 65-79.

Vidya R, Venkatesan K. Preparation and characterization of zinc ferrite $\left(\mathrm{ZnFe}_{2} \mathrm{O}_{4}\right)$ nanoparticles using self-propagated combustion route and evaluation of antimicrobial activity. Res J Pharma Biol Chem Sci, 2015; 6 (1): 537-542.

Xavier S, Cleetus H, Nimila PJ, Thankachan S, Sebastian RM, Mohammed EM. Structural and antibacterial properties of silver substituted cobalt ferrite nanoparticles. Res J Pharma Biol Chem Sci, 2014; 5 (5): 364-371.

Yamamoto O. Influence of particle size on the antibacterial activity of zinc oxide. Int J Inorg Mater, 2001; 3:643-646.

Yan CH. Nanophased $\mathrm{CoFe}_{2} \mathrm{O}_{4}$ prepared by combustion method. Solid State Commun, 1999; 111(5): 87-291.

\section{How to cite this article:}

Hathout AS, Aljawish A, Sabry BA, El-Nekeety AA, Roby MH, Deraz NM, Aly SE, Abdel-Wahhab MA. Synthesis and characterization of cobalt ferrites nanoparticles with cytotoxic and antimicrobial properties. J App Pharm Sci, 2017; 7 (01): 086-092. 